\title{
Ophiolite Emplacement and the Effects of the Subduction of the Active Chile Ridge System: Heterogeneous Paleostress Regimes Recorded in the Taitao Ophiolite (Southern Chile)
}

\author{
Eugenio E. Veloso ${ }^{1,2}$, Ryo Anma², Atsushi Yamaji ${ }^{3}$ \\ ${ }^{1}$ Facultad de Ingeniería y Ciencias Geológicas, Departamento de Ciencias Geológicas, Universidad Católica del Norte, Av. Angamos \\ 0610, Antofagasta, Chile. \\ eveloso@ucn.cl \\ 2 Graduate School of Life and Environmental Sciences, University of Tsukuba, Tsukuba 305-8572, Japan. \\ anma@arsia.geo.tsukuba.ac.jp \\ ${ }_{3}$ Division of Earth and Planetary Sciences, Graduate School of Sciences, Kyoto University, Kyoto 606-8502, Japan. \\ yamaji@kueps.kyoto-u.ac.jp
}

\begin{abstract}
The repeated north and southward migration of the Chile Triple junction, offshore the Península de Taitao, is expected to have imposed contrasting stress fields in the forearc for the last $6 \mathrm{Ma}$ because of changes in convergence direction and rate of subducting plates. NNW-SSE to E-W and minor NE-SW striking brittle faults developed in the plutonic units of the Mio-Pliocene Taitao Ophiolite, whereas NNE-SSW and minor NW-SE trending faults developed in its eastern border (Bahía Barrientos fault-zone). These brittle faults are studied to elucidate the style of ophiolite emplacement and the tectonic effects resulting from the alternated migration of the Chile Triple junction in the area. Analyses of heterogeneous fault-slip data on both areas suggest that faults were activated by different stress fields. Two different compressional stress fields were identified in the plutonic units (A and B), whereas three different stress fields, ranging from compressional to strike-slip, were identified in the Bahía Barrientos fault-zone (C, D and E). Calculated directions of $\sigma_{1}$ axes for A, C, D and E solutions are mostly E-W trending, roughly similar to the convergence direction of subducting plates, whereas that for $\mathrm{B}$ solution is counterclockwise rotated $c a .60^{\circ}$ with respect to the previous $\mathrm{E}-\mathrm{W}$ trend. Brittle structures related to solution B were attributed to an early deformation of the ophiolite, most probably developed shortly after its emplacement ( $c a .6 \mathrm{Ma}$ ). These structures were further counterclockwise rotated, while new structures (related to solution A) developed in the plutonic units in order to absorb the continuous deformation. In the eastern margin of the ophiolite, the stress field divided into compressional and strike-slip components. During periods of relatively strong compression (fast subduction of the Nazca plate), the fault-zone experienced well defined compressional and strike-slip movements (solutions C and D). In contrast, during periods of relatively weak compression (slow subduction of the Antarctic plate), the fault-zone experienced a complex mixture of thrust and strike-slip movements (solution E). Thus, the wide range of calculated stress ratios for all solutions could be attributed to the alternated change in convergent velocity of the subducting plates beneath the Taitao area.
\end{abstract}


RESUMEN. Emplazamiento de ofiolitas y los efectos de la subducción de la dorsal activa de Chile: Regímenes heterogéneos de paleostress registrados en la Ofiolita Taitao (Sur de Chile). Es esperable que la repetida migración norte-sur del Punto Triple de Chile cercana a la costa de la Península de Taitao haya impuesto campos de esfuerzos distintos en el antearco por los últimos $6 \mathrm{Ma}$ debido a cambios en la dirección de convergencia y tasa de subducción. Fallas con rumbos NNO-SSE y E-O y otras menores con rumbos NE-SO se desarrollaron en las unidades plutónicas de la Ofiolita Miocena-Pliocena de Taitao, mientras que fallas con rumbos NNE-SSO y otras menores con rumbos NO-SE se desarrollaron en el borde Este de esta (Zona de falla de Bahía Barrientos). Estas estructuras frágiles son estudiadas para dilucidar el estilo de emplazamiento de la ofiolita y los efectos tectónicos resultantes de la migración alternada del Punto Triple de Chile en al área. Análisis de datos heterogéneos de fallas en ambas áreas sugieren que fueron activadas por campos de esfuerzos diferentes. Dos campos de stress compresionales distintos fueron identificados en las unidades plutónicas (A y B), mientras que 3 campos de stress diferentes, desde compresionales a transcurrentes, lo fueron en la zona de falla de Bahía Barrientos (C, D y E). Las direcciones de los ejes $\sigma_{1}$ calculadas para las soluciones A, C, D y E son principalmente este-oeste, similares a la dirección de convergencia de las placas subductantes, mientras que aquella para la solución $\mathrm{B}$ está rotada antihorario $c a .60^{\circ}$ con respecto del patrón anterior este-oeste. Las estructuras frágiles relacionadas con la solución $\mathrm{B}$ fueron atribuidas a una deformación temprana de la ofiolita, muy probablemente desarrolladas después de su emplazamiento (ca. $6 \mathrm{Ma}$ ). Estas estructuras fueron posteriormente rotadas antihorario, mientras nuevas estructuras (relacionadas con la solución A) se desarrollaron en las unidades plutónicas para absorber la deformación continua. En el margen este de la ofiolita, el campo de esfuerzo se dividió en componentes compresionales y transcurrentes. Durante períodos de compresión relativamente alta (subducción rápida de la placa de Nazca) la zona de falla experimentó movimientos compresionales y transcurrentes bien definidos (soluciones $\mathrm{C}$ y D). En contraste, durante períodos de relativa baja compresión (lenta subducción de la placa Antártica) la zona de falla experimentó una compleja mezcla de movimientos inversos y transcurrentes (solución E). Así, el amplio rango de radios de stress calculados para todas las soluciones puede ser atribuido al cambio alternado en la velocidad de convergencia de las placas subductantes bajo el área de Taitao.

Palabras claves: Deformaciones frágiles, Paleostress, Campos de stress heterogéneos, Ofiolita Taitao, Punto Triple de Chile.

\section{Introduction}

The processes of emplacement and the tectonic evolution of the Late-Miocene Taitao Ophiolite (southern Chile) has long been a matter of debate, although is one of the best natural examples of ophiolite emplacement and ridge-trench interaction (e.g., Lagabrielle et al., 2000). The Taitao Ophiolite is located approximately at $75^{\circ} 30^{\prime} \mathrm{W}$ and $46^{\circ} 40^{\prime} \mathrm{S}$, at the westernmost point of the southern coast of Chile (Fig. 1a). It consists of a complete sequence of oceanic lithosphere including ultramafic rocks, gabbros, dike complexes and volcaniclastic rocks (Fig. 1b). All these rock units are northward tilted (Nelson et al., 1993; Lagabrielle et al., 2000; Veloso et al., 2005) and surrounded by young plutonic intrusions (Mpodozis et al., 1985; Lagabrielle et al., 1994; Guivel et al., 1996, 1999; Hervé et al., 2003).

Several authors have pointed to a close spatial and temporal relation between the processes of 6 Ma ophiolite emplacement (Anma et al., 2006) and the evolution of the active Chile Ridge system that separate the Nazca (to the north) and Antarctic (to the south) oceanic plates (e.g., Cande and Leslie, 1986; Forsythe and Nelson, 1985; Nelson et al., 1993; Keading et al., 1990; Bourgois et al., 1996;
Lagabrielle et al., 1994, 2000; Veloso et al., 2005). According to global plate reconstructions and numerical models (e.g., NUVEL1-A) the Nazca plate is presently subducting at a rate of about 8.5 $\mathrm{cm} / \mathrm{yr}$ in a $\mathrm{N} 80^{\circ} \mathrm{E}$ direction whereas the Antarctic plate subducts at a rate of $c a .2 \mathrm{~cm} / \mathrm{yr}$ in a $N 90^{\circ} \mathrm{E}$ direction (Fig. 1a) (e.g., Cande and Leslie, 1986; DeMets et al., 1994; Somoza, 1998). The Nazca and Antarctic oceanic plates are separated by the Chile Ridge System, which is presently subducting beneath the South American plate $c a .40 \mathrm{~km}$ north of the Taitao area and defining a triple junction named 'Chile Triple Junction'. The obliquity of convergent directions and orientation of the active Chile Ridge system resulted in an alternated north and southward migration of the Chile Triple junction (Cande and Leslie, 1986). Because of this migration pattern, three different segments of the Chile Ridge system collided with the western border of the South American plate offshore the Península de Taitao at $c a .6$ Ma, ca. $3 \mathrm{Ma}$ and $0.3 \mathrm{Ma}$ to Present (Cande and Leslie, 1986). The particular configuration of the active Chile Ridge system, the alternated migration pattern and the change in convergent directions and velocities are expected to induce contrasting stress conditions in the forearc (e.g., Forsythe and Nelson, 


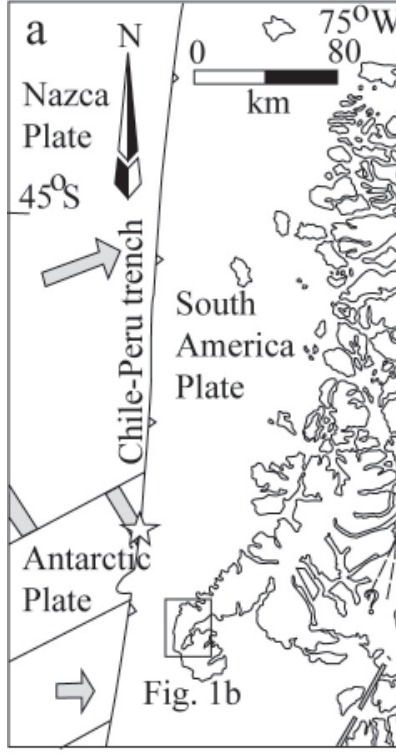

- Mpodozis et al. (1985)

$\mathrm{K}-\mathrm{Ar}$ (whole rock) $\mathrm{K}-\mathrm{Ar}$ (biotite) : b $\mathrm{K}-\mathrm{Ar}$ (hornblende) $: \mathrm{h}$

- Guivel et al. (1999) $\mathrm{Ar} / \mathrm{Ar}$ (biotite) : b Ar/Ar (feldspar) : f

○ Hervé et al. (2003) SHRIMP U-Pb zircon FT (zircon) : zr FT (apatite) : ap

$\square$ Anma et al. (2006) SHRIMP U-Pb zircon FT (zircon) : zr

Unconformity

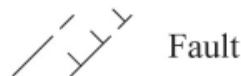

' Primary boundary b
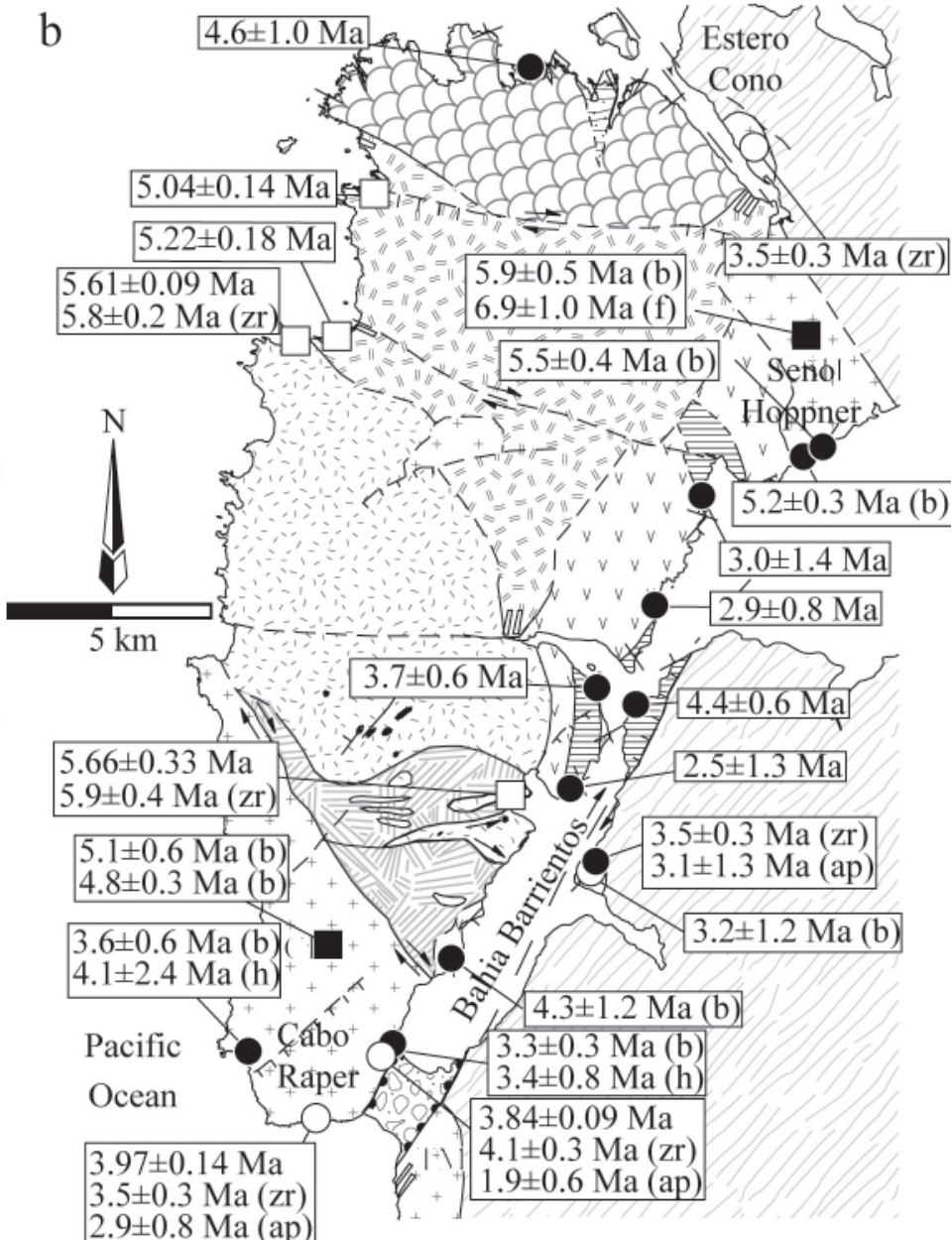

Taitao ophiolite

Mudstone/Sandstone

Others

/Conglomerate

Main Volcanic Unit

Sheeted dike complex

Gabbro

Ultramafic rock

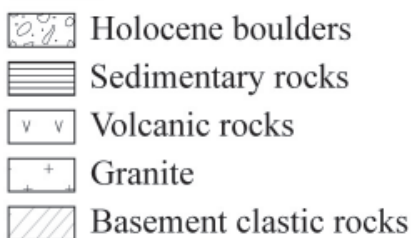

FIG. 1. a. Major structural features offshore the Península de Taitao. The star indicates the present-day location of the Chile Triple junction; b. Geological map of the westernmost portion of the Península de Taitao, including available ages determined by several authors (filled and non-filled squares and circles indicate the locality in where ages were determined).

1985; Yáñez and Cembrano, 2000, 2004) and the entire belt (Lagabrielle et al., 2004).

Theoretically, the internal structures of any accreted ophiolite can potentially provide information related to the successive stress fields that this ophiolite experienced from its generation to its emplacement. Thus, it is necessary to separate the structures generated during spreading ridge processes, as for example those present in the Troodos Ophiolite (Moores and Vine, 1971; Varga and Moores, 1985; Dilek et al., 1990), from those related to the emplacement process. Nelson et al. 
(1993) pointed that most of the brittle deformation observed in the Taitao Ophiolite is a direct result of its emplacement process. Hence, brittle structures present in the central part and in the easternmost margin of the ophiolite and of the nearby forearc domain may become a key to understand the changing stress field induced by the subduction of the Chile Ridge system.

In this study we report the results of paleostress analyses of structural data collected from the plutonic section of the Taitao Ophiolite and from the major lineament that bounds the ophiolite in the East (the Bahía Barrientos fault-zone). Calculated patterns of stress field were studied in order to reveal the different stress fields that were involved during the emplacement process, their relation to previously reported rotations and to the effects of the migration of the Chile Triple junction in the area.

\section{The Brittle Deformation of the Taitao Ophiolite}

Previous works on the Península de Taitao (e.g., Forsythe and Nelson, 1985; Nelson et al., 1993; Guivel et al., 1996; Lagabrielle et al., 2000; Veloso et al., 2005) showed that the Taitao Ophiolite is in fault contact with surrounding Pre-Jurassic basement and young $(<4 \mathrm{Ma})$ Cabo Raper pluton in the south (Forsythe and Nelson, 1985; Guivel et al., 1996; Nelson et al., 1993; Hervé et al., 2003; Veloso et al., 2005). Internal lithological boundaries of the ophiolite (Fig. 1b) were inferred mostly to be fault contacts, based on our own field observations and interpretation of aerial photographs.

Forsythe and Nelson (1985) reported thrust, normal and strike-slip brittle faults in the easternmost margin of the Península de Taitao. In this study, reported fault data was mainly collected from the plutonic units of the ophiolite (gabbros and ultramafic rocks) and from the coastal outcrops in the northern and central parts of the Bahía Barrientos fault-zone developed mostly in volcaniclastic deposits of the Chile Margin Unit (e.g., Bourgois et al., 1993; Nelson et al., 1993) (Fig. 1b) in the eastern part of the ophiolite. These rock units were chosen because they recorded the deformation that affected the interior and the border of the ophiolite, respectively; providing contrasting and complementary information about the emplacement and accommodation processes.
Ultramafic rocks show different geochemical affinities and commonly present strong serpentinization (e.g., Nelson et al., 1993), whereas gabbros commonly present compositional layering and well preserved primary structures (such as folds and compositional grading). The Chile Margin Unit is composed of thick deposits of highly vesicular pillow lavas and pillow breccias (Bourgois et al., 1993; Nelson et al., 1993; Lagabrielle et al., 2000) interbedded with conglomerates and sandstones. According to Guivel et al. $(1996,1999)$ this unit was emplaced close to its actual location, and perhaps as a result of the counterclockwise rotation of the ophiolite package (Veloso et al., 2005).

Little information about the internal brittle structures of the ophiolite was available until now. Brittle structures developed in the inner parts of plutonic units (gabbros and ultramafic rocks) of the ophiolite are not only restricted to fault contacts between different lithologies. We found and documented abundant meter-scale fault planes with dip-slip and/or strike-slip movements in the surrounding areas of the contact between ultramafic and gabbroic rocks (Fig. 2) during two expeditions (summers of 2000-2001 and 2003-2004). Two sets of brittle faults were recognized, one with mainly NNW-SSE to E-W trends and other with NE-SW trends (Fig. 2a). Both sets are characterized by low angle fault planes that dip towards north and south. Major structures can be followed several meters until they are covered by the dense vegetation or submerged into Bahía Barrientos waters. No gouge was observed, yet fault planes present kinematic indicators such as those described by Petit (1987) and Doblas (1998). These indicators suggest thrust movements with small strike-slip components. Orientations of fault planes and of their kinematic indicators together with inferred senses of movement are plotted on figure $2 \mathrm{a}$.

Crosscutting relationships between identified sets are complex; NE-SW trending fault planes commonly cut and displace NNW-SSE to E-W trending ones, yet opposite relationships were also observed at some places. This complex crosscutting relationship suggests that activity of both sets was most probably synchronous.

Faults with scattered orientations were observed in the dike complex and volcaniclastic units of the ophiolite, in where the relative displacement of bedding markers indicate a normal movement. This suggests a NE-SW extension in the northern 

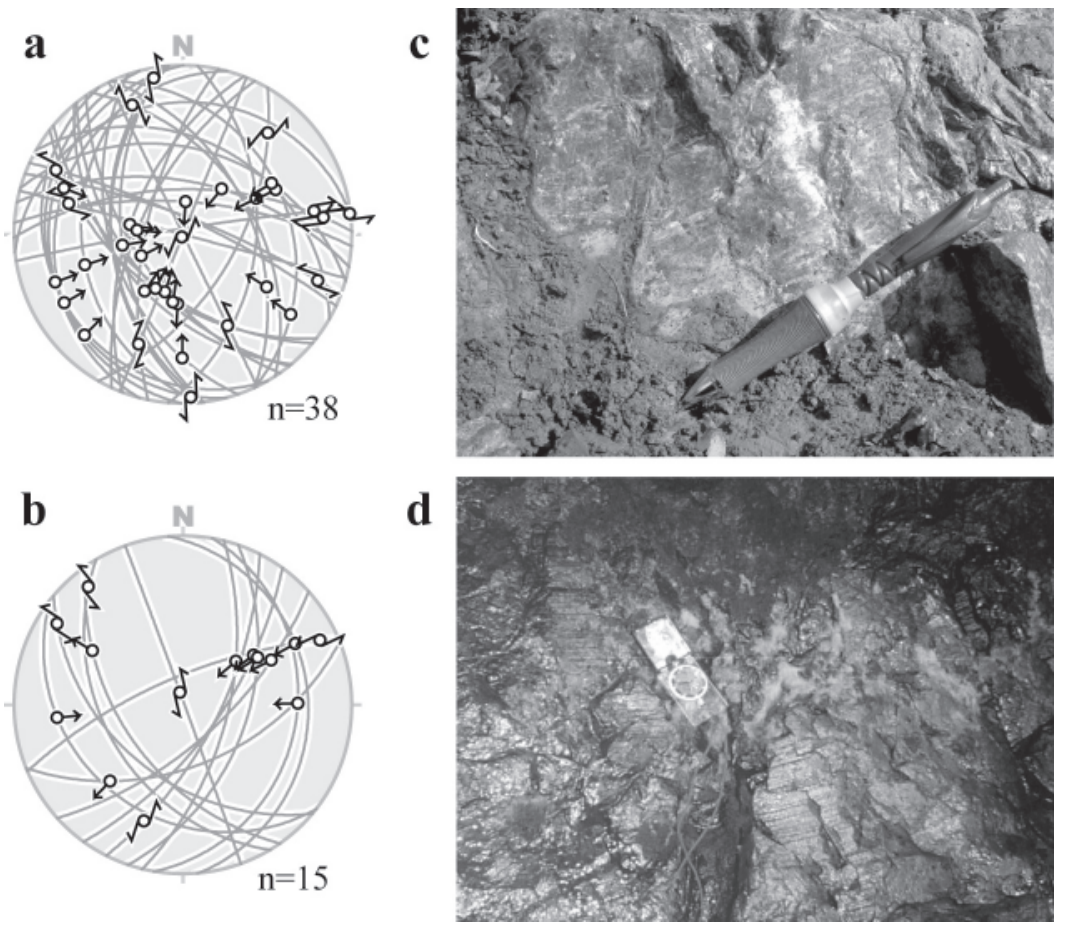

FIG. 2. Lower hemisphere, equal areaprojection with orientations of fault-slip data used in this study; a. plutonic units; b. Bahía Barrientos fault-zone. ' $n$ ' refers to the number of fault-slip data collected on each area. Typical outcrops of faults developed in c. the plutonic units and in d. the Bahía Barrientos Fault Zone.

part of the ophiolite. Veloso et al. (2005) suggested that such extension was a direct result of a counterclockwise rotation of the ophiolite sometime after 6 Ma due to its emplacement and accommodation into the forearc. No kinematic indicators -such as those described by Petit (1987) and Doblas (1998)- were observed on these faults, and therefore they were excluded from the further analysis.

The Bahía Barrientos fault-zone corresponds to a major lineament in the Península de Taitao (Bourgois et al., 1993; Nelson et al., 1993), extending from the southernmost tip of the Cabo Raper pluton in the south towards NNE until it submerges under the water at Seno Hoppner bay (Fig. 1b). Two set of fault planes, one striking NNW-SSE and dipping moderately to the west and other striking NE-SW and dipping to the east, are present in ultramafic rocks and gabbros in the southern part along the coast of Bahía Barrientos as well as in several volcaniclastic outcrops in the eastern border of the peninsula (Chile Margin Unit; Figs. 1b and 2b) (Forsythe and Nelson, 1985; Nelson et al., 1993; Veloso et al., 2005).

In the southern portion of the Bahía Barrientos fault-zone strike-slip and/or thrust movements were inferred from the orientations of kinematic indicators as well as from the relative displacements of bedding markers (Fig. 2). On the contrary, in the northern portion of the fault-zone normal and/or strike-slip movements were inferred. The orientations of individual fault planes and of inferred senses of movement suggest mainly dextral strikeslip movement for the fault-zone with minor vertical components (either normal or thrust), perhaps similar to a scissors fault. Orientations of fault planes and of their kinematic indicators together with inferred senses of movement are plotted on figure $2 b$.

\section{The Multiple Inverse Method and Fault Data Sampling}

Stress tensor inversion is a method for determining stress fields from fault-slip data obtained from outcrops, borehole cores or active seismic clusters (Angelier, 1994; Ramsay and Lisle, 2000). Among several computer routines and numerical techniques the 'multiple inverse method' is designed to separate stress fields from heterogeneous faultslip data which recorded polyphase stress histories (Yamaji, 2000; Otsubo and Yamaji, 2006). The graphic interface of the method allows an easy and fast separation of different stress fields recorded on the fault-slip data. The method is an adaptation of 
the generalized Hough Transform (Ballard, 1981; Yamaji, 2000). It assumes that a sub-population (containing a number of k-elements) of the heterogeneous fault-slip data responds to the Wallace-Bott hypothesis (e.g., Angelier, 1994), thus allowing determination of the principal stress axes associated to it. A cluster analysis of the obtained solutions for each one of all possible sub-sets allows the identification of homogeneous stress fields recorded within a heterogeneous population of fault-slip data (see Yamaji et al., 2000 and Otsubo and Yamaji, 2006, for details). To apply this method fault-slip data must include the orientation of the fault plane and of the striae (or some other kinematic indicator) plus the sense of movement. In this study the version 5.31 of the 'multiple inverse method'(Otsubo and Yamaji, 2006) was used to analyze collected brittle fault-slip data.

The output of the method is shown in a pair of stereograms containing the orientations of the principal maximum $\left(\sigma_{1}\right)$ and minimum $\left(\sigma_{3}\right)$ stress axes (Fig. 3). Each sub-solution is represented by a tadpole indicating the orientation of one of the principal axis with an attached 'tail' pointing towards the orientation of the complementary principal axis (i.e., $\sigma_{1}$ 's tadpole points toward the orientation of $\sigma_{3}$ and vice versa). The tadpole is, additionally, color coded according to the calculated stress ratio obtained through the relation $\left(\sigma_{2}-\sigma_{3}\right) /\left(\sigma_{1}-\right.$ $\sigma_{3}$ ). Thus, groups of tadpoles with similar colors and with similar orientations of their tails indicate a single stress field solution (e.g., Yamaji, 2000; Otsubo and Yamaji, 2006). Resolution and visualization of obtained solutions can be enhanced using a couple of numerical parameters; 'k' which defines the number of data contained on each sub-set, and 'e'which enhances the resolution, allowing to thin out erroneous solutions and enhance correct ones (see Otsubo and Yamaji, 2006 for details).

\section{Paleostress Results}

Numerical parameters used for this study were $\mathrm{k}=5$ and $\mathrm{e}=11$, which were found to be optimal for the current data set. The output of the method revealed different stress fields on both studied areas (plutonic units and Bahía Barrientos fault-zone) (Fig. 3), suggesting a complex polyphase brittle deformation history for the emplacement process of the ophiolite.
Two different stress field solutions were obtained from fault-slip data collected from the plutonic units of the ophiolite (ultramafic rocks and gabbros); these were labeled solutions 'A' and 'B' (Fig. 3a). Solutions have their $\sigma_{1}$ axes oriented close to the horizontal plane, but with different azimuths and stress ratios values. On the contrary, they have a common vertical orientation of their $\sigma_{3}$ axes (Fig. 3a). Hence, these solutions represent compressional stress fields. Calculated range of stress ratios are similar; the one for solution 'A' ranges between $c a .0 .2$ and $c a$. 0.9 while the one for solution ' $\mathrm{B}$ ' ranges between $c a$. 0.4 and 0.7 (Fig. 4).

Orientations of $\sigma_{1}$ axes of solution ' $A$ ' are widespread, varying between NW-ward and SSW-ward azimuths (Fig. 3). A statistical analysis of these orientations indicates that they follow an elliptical distribution (e.g., Kent, 1992), with a westward mean orientation (Table 1). However, this mean orientation cannot be considered as fully representative of an imposed stress field since it only considers the orientation of the axes and not their associated stress ratio values. Thus, the nearly westward oriented compressional axis of solution ' $\mathrm{A}$ ' is considered here as a first-order approximation.

In contrast to solution ' $A$ ', azimuths of $\sigma_{1}$ axes of solution 'B' are mainly SW-ward oriented. Following the same procedure, the first approximation of the mean orientation of the compressional axis for solution ' $\mathrm{B}$ ' trends nearly SW-ward (Table 1).

For fault-slip data collected from the southern and central parts of the Bahía Barrientos fault-zone (mostly in volcaniclastic deposits of the Main Volcanic Unit), three different stress field solutions were obtained. These were labeled solutions ' $C$ ', 'D' and 'E' (Fig. 3b). Similar to solutions 'A' and 'B', orientations of $\sigma_{1}$ axes for these solutions are oriented close to the horizontal plane indicating a general E-W to SWW-NEE compression. Exceptions are the orientations of some axes of solution 'E', which have steepest plunge angles related to SW-ward to southward azimuths.

Orientations of $\sigma_{3}$ axes for these solutions vary from nearly vertical (solution ' $C$ ') to nearly horizontal (solution 'D'). Namely, calculated solutions represent a wide range of stress fields between nearly compressional (solution ' $\mathrm{C}$ ') and nearly strike-slip (solution ' $D$ ') regimes. Calculated stress ratios also vary; for solution ' $\mathrm{C}$ ' it ranges between 

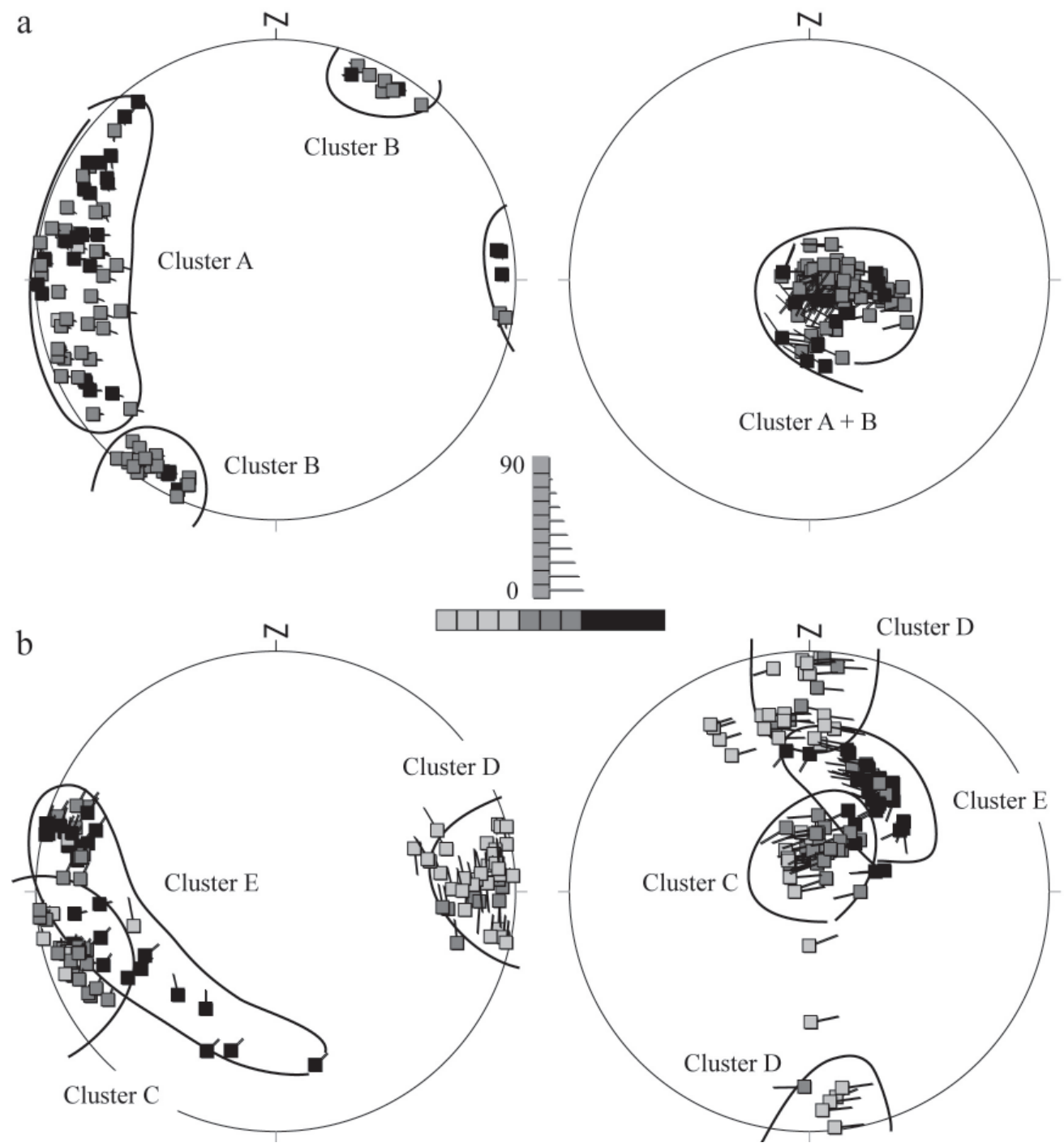

FIG. 3. Lower hemisphere, equal area projection with the orientations of the stress field solutions calculated in this study. a. plutonic units; b. Bahía Barrientos fault-zone. Left side stereograms correspond to the maximum stress axes $\left(\sigma_{1}\right)$ while right side ones correspond to the minimum stress axes $\left(\sigma_{3}\right)$. Color keys for stress ratios and plunge of tadpole symbols are indicated as horizontal color bar and vertical bar with tails of tadpoles of different lengths, respectively.

ca. 0.1 and $c a$. 0.7 , for solution ' $\mathrm{D}$ ' between $c a .0 .1$ and 0.8 and for solution 'E' between $c a$. 0.4 and $c a$. 0.9 (Figs. 3b and 4).

Orientations of $\sigma_{1}$ axes for solution ' $\mathrm{C}$ ' are well-clustered in subhorizontal SWW-ward plunging point maximum. The orientations of these axes follow an elliptical distribution with a mean azimuth of $c a .253^{\circ}$ (Table 1). Similarly, the orientations of related $\sigma_{3}$ axes are well-clustered, following also an elliptical distribution with a mean northward azimuth and a plunge angle of $c a .75^{\circ}$.

Orientations of $\sigma_{1}$ axes of solution ' $\mathrm{D}$ ' plot on a subhorizontal eastward plunging point maximum, similar to those of solution ' $\mathrm{C}$ '. The orientations of these axes also follow an elliptical distribution, with nearly eastward azimuths oriented close to the horizontal plane. In contrast to solution ' $C$ ', $\sigma_{3}$ axes of solution ' $\mathrm{D}$ ' are oriented near to the horizontal 
TABLA 1. FIRST-ORDER STATISTICAL PARAMETERS OF CALCULATED SOLUTIONS.

\begin{tabular}{crrrrrrrrrrr}
\hline Stress field axis & Dec & Inc & N & K & $\boldsymbol{\eta}$ & $\boldsymbol{\eta}$ dec & $\boldsymbol{\eta}$ inc & $\zeta$ & $\zeta$ dec & $\zeta$ inc \\
\hline A- $\sigma_{1}$ & 271 & 14 & 56 & 12 & 2 & 92 & 75 & 8 & 1 & 0.3 \\
A- $\sigma_{3}$ & 120 & 77 & 56 & 47 & 2 & 322 & 12 & 3 & 231 & 5 \\
B- $\sigma_{1}$ & 213 & 3 & 30 & 223 & 0.4 & 79 & 85 & 3 & 303 & 4 \\
B- $\sigma_{3}$ & 71 & 86 & 30 & 193 & 1 & 194 & 2 & 2 & 284 & 3 \\
C- $\sigma_{1}$ & 253 & 6 & 33 & 72 & 2 & 53 & 55 & 4 & 159 & 35 \\
C- $\sigma_{3}$ & 7 & 75 & 33 & 104 & 2 & 119 & 6 & 3 & 210 & 14 \\
D- $\sigma_{1}$ & 88 & 19 & 30 & 34 & 4 & 192 & 34 & 5 & 335 & 50 \\
D- $\sigma_{3}$ & 351 & 15 & 30 & 10 & 5 & 83 & 7 & 11 & 198 & 74 \\
E- $\sigma_{1}$ & 269 & 25 & 42 & 8 & 2 & 34 & 51 & 12 & 165 & 28 \\
E- $\sigma_{3}$ & 37 & 51 & 42 & 51 & 2 & 241 & 36 & 4 & 142 & 12 \\
\hline
\end{tabular}

Dec and Inc refer to the declination (azimuth) and inclination (plunge) of the mean direction for the stress axis, respectively. $\mathrm{N}$ is the number of calculated stress axes obtained for each solution by means of the multiple inverse method analysis, K is the Fisher's (1953) precision parameter. ' $\eta$ ' and ' $\zeta$ ' are the minimum and maximum $95 \%$ confidence angles, respectively, centered on the intersection of the planes given by the poles with coordinates ' $\eta$ dec', ' $\eta$ inc' and ' $\zeta$ dec', ' $\zeta$ inc' (see Tauxe (1998) for details of Kent's (1992) statistics parameters).

plane with a mean northward azimuth (Table 1). Differences in the orientations among $\sigma_{3}$ axes of solutions ' $\mathrm{C}$ ' and ' $\mathrm{D}$ ', as well as the difference in their stress ratios, suggest that these solutions represent different stress fields.

The orientations of $\sigma_{1}$ axes of solution ' $E$ ' range between southward and NWW-ward azimuths; mainly clustered in a NNW-ward direction (Fig. $3 \mathrm{~b})$. This wide range in the orientations of $\sigma_{1}$ axes is similar to that observed for solution ' $A$ '. Orientations of the $\sigma_{1}$ axes of solution ' $\mathrm{E}$ ' are slightly overlapped with those of solution ' $\mathrm{C}$ '. This makes difficult separation between these two solutions, yet differences in their stress ratios help to separate them (Fig. 5). Orientations of the $\sigma_{3}$ axes of solution ' $E$ ' are clustered about a mean orientation of $c a$. $36^{\circ} / 51^{\circ}$ (azimuth/plunge) (Table 1), and few of them overlap with solutions ' $C$ ' and ' $D$ '. Again, differences in stress ratio help to distinguish between these solutions, as well as the orientations of their related tadpoles (Fig. 3).

\section{Discussion}

Analysis of heterogeneous fault-slip data reveal a complex brittle deformation pattern for the plutonic units of the Taitao Ophiolite and for the southern and central parts of the Bahía Barrientos fault-zone. In the plutonic units of the ophiolite we determined two different compressional stress fields whereas in the Bahía Barrientos fault-zone we determined three different ones (ranging between compressional and strike-slip) (Fig. 3). Orientations of calculated $\sigma_{1}$ axes (for all obtained solutions) agree with those previously reported by Forsythe and Nelson (1985); i.e., a main E-W compression most probably resulted from the subduction of the Chile Ridge system and the two oceanic plates (Nazca and Antarctic) offshore the Taitao area. However, there are some important differences among obtained solutions.

The mean orientation of the $\sigma_{1}$ axis of solution ' $\mathrm{B}$ ' is counterclockwise rotated $c a .60^{\circ}$ with respect to the orientation of the $\sigma_{1}$ axis of solution ' $A$ '. This suggests, preliminarily, that two different compressional events affected the ophiolite; a westward oriented compressional event and a SWward one. However, stress field imposed on the area for the last 6 Ma has been mainly due to the eastward subduction of the Chile Ridge system and the two oceanic plates (Yáñez and Cembrano, 2000; Yáñez et al., 2002). 
Veloso et al. (2005) suggested that the plutonic units of the ophiolite experienced a large counterclockwise rotation after $6 \mathrm{Ma}$ based on paleomagnetic analyses. A consistent explanation for the different orientations of $\sigma_{1}$ axes of solutions ' $A$ ' and ' $B$ ' is that solution ' $B$ ' represents a counterclockwise rotated portion of solution ' $A$ '. This is supported by the similarities among the stress ratios of both solutions, both roughly following a normal distribution with similar mean and standard deviation values (Figs. 4 and 5).

The complex crosscutting relationships among the different sets of brittle structures developed in the plutonic units and the similar stress ratio values between solutions ' $A$ ' and ' $B$ ' suggest that the compression imposed on the ophiolite was similar before and after the rotation. The wide range of orientations of the $\sigma_{1}$ axes of solution 'A' could then be attributed to fault activities (or development) synchronous to rotation (Fig. 3a). Early generated brittle structures were most probably the result of compression imposed by the subduction of the Chile Ridge system, and then rotated while new brittle reverse slip structures developed in response to the continuous compression.

The $\sigma_{1}$ axes of solutions 'C', 'D' and 'E' are similarly oriented in E-W directions; compatible with the compressional direction expected from the subduction of the Chile Ridge system and the two oceanic plates offshore the Taitao area. The main difference between these three solutions is the orientation of their minimum principal stress $\left(\sigma_{3}\right)$ axes (Fig. 3b). These are clearly clustered in three different orientations arranged in a N-S great circle, probably representing a rotation of the $\sigma_{3}$ axis about an E-W horizontal axis.

In particular, orientations of principal stress axes of solution ' $\mathrm{C}$ ' are similar to orientations of

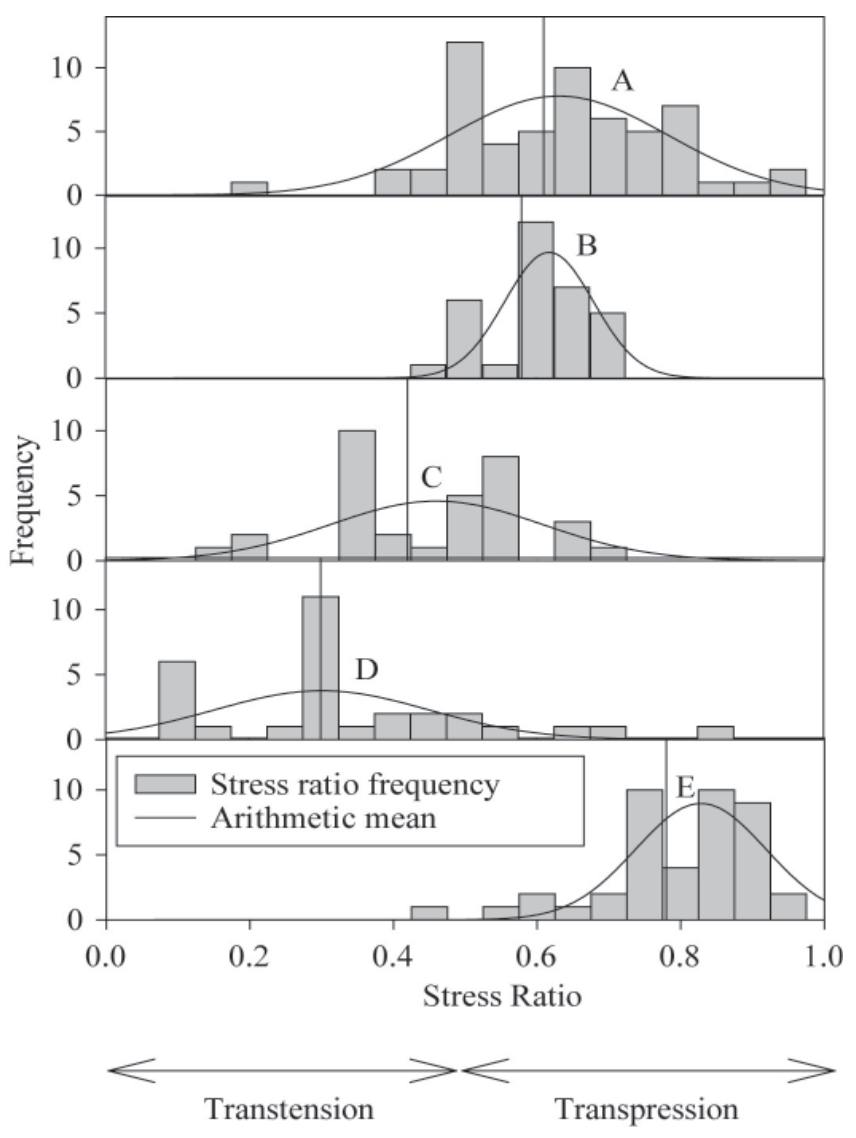

FIG. 4. Histograms and best-fitting normal distribution for stress ratio values calculated for each solution (arithmetic mean value is indicated as vertical line on each graph). Letters $\mathbf{A}$ to $\mathbf{E}$ refer to the solutions discussed in the text. Notice the overlap between solutions 'A' and 'B'. 
principal stress axes of solution ' $A$ ', both representing compressional regimes. On the contrary, orientation of the $\sigma_{3}$ axis of solution ' $D$ ' suggests a strike-slip regime, which is consistent with field observations and with the general sense of movement of the Bahía Barrientos fault-zone (Fig. 1). Here, orientation of the $\sigma_{3}$ axis of solution ' $E$ ' suggests that it represents an intermediate (or connecting) stress state between solutions ' $C$ ' and ' $D$ ' (Figs. 3 and 5).

The different obtained solutions and the orientations of their principal stress axes suggest that the stress field imposed by the subduction of the Chile Ridge system divided into two components; one mainly compressional and other mainly transcurrent. Such division of the stress field (e.g., Fitch, 1972) has been proposed for other parts of the Andean orogen, like for example the Chiloé block north of the Península de Taitao (e.g., Forsythe and Nelson, 1985; Nelson et al., 1994) and, in particular, for the dextral transpression documented in the arc at the latitude of the Península de Taitao associated in time and space to the subduction of the Chile Ridge system (Cembrano et al., 2002; Thomson, 2002).

According to Yáñez and Cembrano (2000) and Yáñez et al. (2002) the subduction of the Chile Ridge system imposes different stress regimes in the forearc; south of the Chile Triple junction the stress field is expected to be transtensional due to the slow subduction of the Antarctic plate (ca. $2 \mathrm{~cm} /$ year; Cande and Leslie, 1986; DeMets, 1994; Somoza, 1998), while north of it is expected to be transpressional due to the fast subduction of the Nazca plate (ca. $8.5 \mathrm{~cm} /$ year; Cande and Leslie, 1986; DeMets, 1994; Somoza, 1998). The change in stress regime, or velocity of subducting oceanic plate, might be thus reflected in the stress ratios of the different solutions. Solutions 'A', 'B' and 'E' correspond to mainly compressional to transpressional solutions (mean stress ratio larger than 0.5 ) while ' $C$ ' and ' $\mathrm{D}$ ' are mainly transtensional to transpressional solutions (mean stress ratios smaller than 0.5) (Fig. 4). Thus, from the different solutions it is possible to observe the stress variability imposed by the alternated north and southward passage of the Chile Ridge system in the area.

A closer analysis of the stress ratios variation and related orientations of their axes gives more information about the repeated passage of the Chile Triple junction in the Taitao area (Fig. 5). For low stress ratio values a clear division of the stress field into compressional (solutions ' $A$ ' and ' $\mathrm{B}$ ') and strike-slip (solution ' $\mathrm{D}$ ') regimes can be observed. On the contrary, for high stress ratio values only compressional stress regimes can be observed. Intermediate stress ratio values (solution 'E') display a complex mixture of both strike-slip and compressional stress regimes. In particular, solution ' $E$ ' corresponds to a mixture between compressional and strike-slip regimes, but orientation of its axes is widespread and they seem to gradually merge with solution ' $C$ ' (Fig. 5). This suggests that solution ' $E$ ' represents a linkage between compressional (solution ' $C$ ') and strike-slip (solution ' $D$ ') regimes, most probably reflecting the change in subducting plate (from Nazca to Antarctic and vice versa) offshore the Taitao area.

Using available ages (e.g., Anma et al., 2006; Guivel et al., 1996; Mpodozis et al., 1985) and global plate tectonic reconstructions of the migration of the Chile Ridge system (Cande and Leslie, 1986) it is possible to establish a relative timing for the different solutions. Previously published fission track and $\mathrm{U}-\mathrm{Pb}$ ages obtained from gabbros indicate that they were uplifted and cooled rapidly just after their generation about 5.7 My ago (Anma et al., 2006). Also, global plate reconstructions have shown that the Chile Ridge system subducted at about $c a .6 \mathrm{Ma}, c a .3 \mathrm{Ma}$ and ca. 0.3-Present (Cande and Leslie, 1986) offshore the Península de Taitao. The brittle deformation event must have occurred during and/or after the ophiolite was incorporated onto the forearc, i.e., after ca. $5 \mathrm{Ma}$. Although there are no constraints to establish a youngest age boundary for the brittle deformation, identified stress fields account for the alternated subduction episodes of the Chile Ridge system.

Variation in the orientation and in the stress ratio values for the different solutions (Fig. 5) suggests that the style of brittle deformation was controlled by the external conditions induced by the subduction of the different oceanic plates (i.e., different convergence directions and velocities). The relative strong compression imposed by the subduction of the Nazca plate for the last ca. $6 \mathrm{Ma}$ (e.g., Cande and Leslie, 1986) can be related to high stress ratio values -represented by transpressional stress ratios- which are clearly divided into strike-slip and compressional regimes in the Bahía Barrientos fault-zone and a mainly compressional regime in the inner part of the ophiolite (Fig. 5). 
a

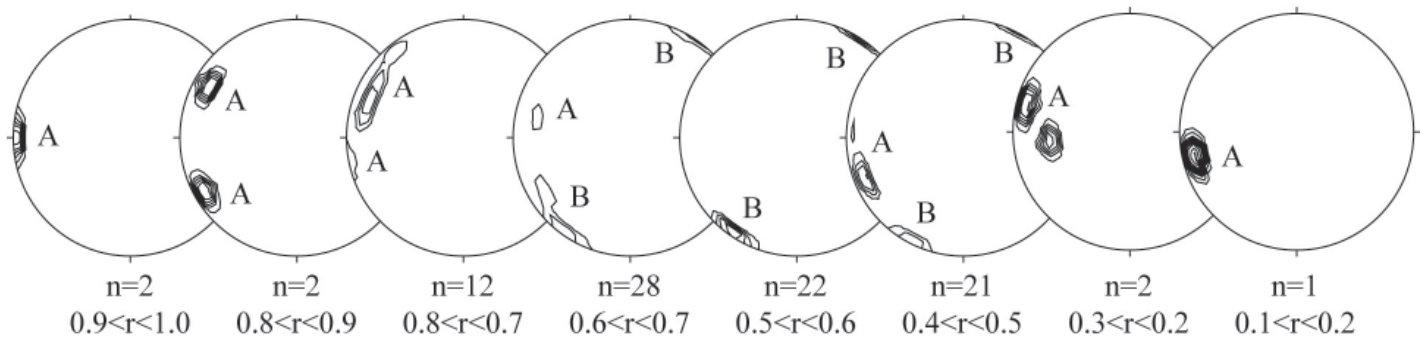

$\mathrm{b}$
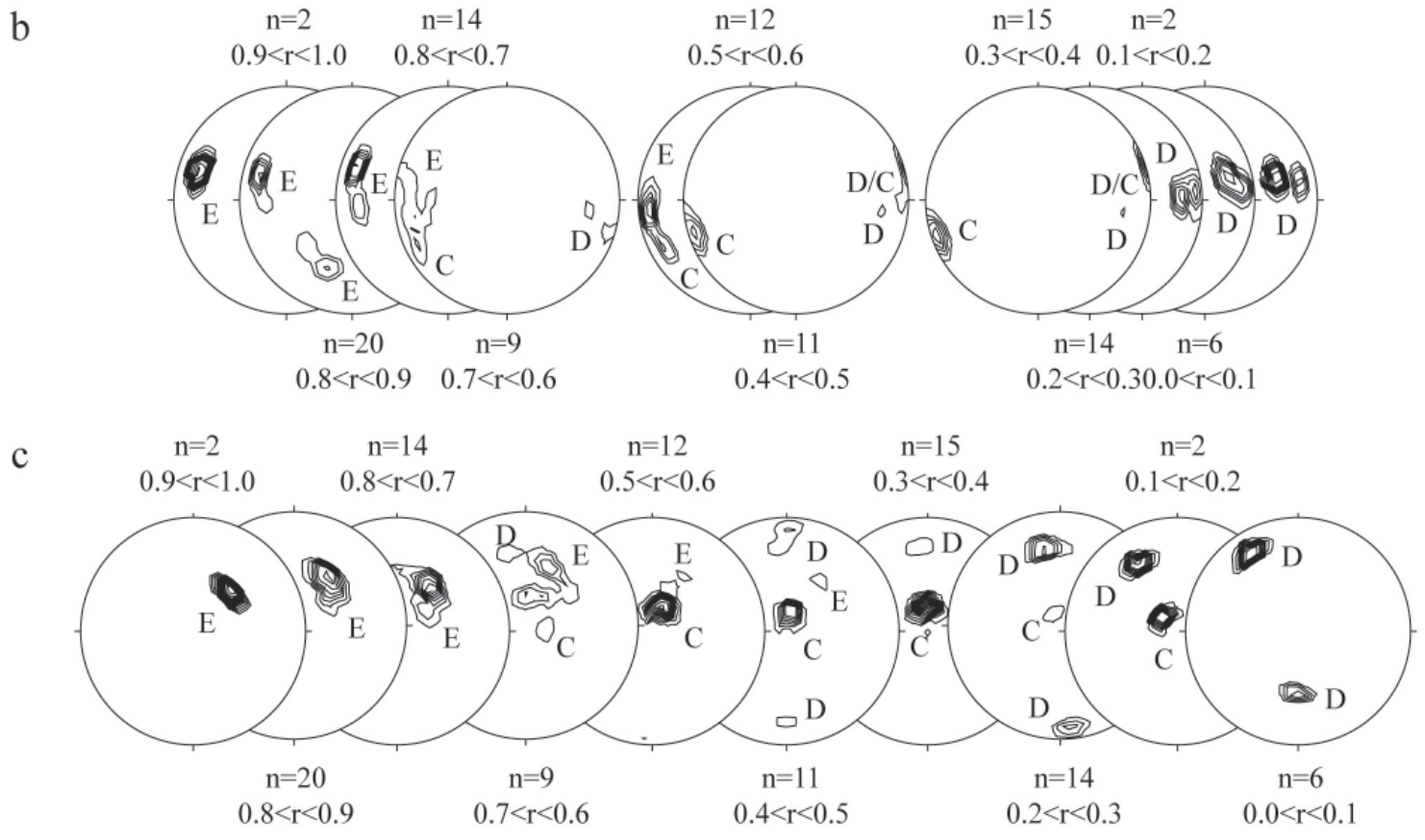

FIG. 5. Density contours (lower hemisphere, equal area projections) of stress axes divided by stress ratio values. a. $\sigma_{1}$ axes of solutions calculated for plutonic units; b. maximum; c. minimum stress axes of solutions calculated for Bahía Barrientos fault-zone. On all plots contours are each 7\%; stress ratio (r) is indicated together with the number of tadpoles used on each plot (cf. Fig. 3).

Here, we propose a tectonic model (Fig. 6) in which all identified stress fields (and related brittle structures) are consistently explained as the result of the subduction of the Chile Ridge system and of the alternated north and southward migration of the Chile Triple junction offshore the Taitao area. In this model, early generated compressional structures developed in the plutonic units of the ophiolite (gabbros and ultramafic rocks) were progressively counterclockwise rotated together with the whole ophiolite (e.g., Veloso et al., 2005), while new structures were generated due to the continuous compression (solutions 'A' and 'B'). Rotated structures were then progressively abandoned due to their incapability to accommodate the imposed deformation. Such behavior and rotation of small faults has been already discussed for complex deformed terranes (e.g., Peacock et al., 1998). Meanwhile, in the eastern border of the ophiolite the mainly dextral transcurrent activity of the Bahía Barrientos fault-zone perhaps drove the counterclockwise rotation of the ophiolite. During periods of relatively strong compression (i.e., subduction of the Nazca plate) the southern and central portion of the fault-zone experienced vertical and strike-slip movements (solutions ' $C$ ' and ' $D$ '); whereas during periods of relatively weak compression (i.e., subduction of the Antarctic plate) the fault-zone experienced a complex mixture of strike-slip and/or vertical movements (solution 'E'). 
This tectonic setting agrees with the general structure of the forearc proposed by Lagabrielle et al. (2000). Deformation of the forearc was dominated by horizontal displacements and tilting of blocks controlled by a network of strike-slip faults generated by the subduction of different segments of the Chile Ridge system offshore the Península de Taitao.

\section{Conclusions}

Brittle structures developed in the plutonic units of the Taitao Ophiolite and in the southern and central parts of the Bahía Barrientos fault-zone (Fig. 1b) were analyzed by using the multiple inverse method (e.g., Otsubo and Yamaji, 2006) in order to reveal the complex tectonic history that affected the ophiolite during and after its emplacement into the South American forearc. Five different stress fields were identified, two from the structures developed in the plutonic units of the ophiolite and three from those present along the Bahía Barrientos fault-zone (Fig. 3). Our conclusions are summarized as follows:
- The alternated change of the subducted oceanic plate (from Nazca to Antarctic and vice versa) beneath the Taitao area induced different stress regimes into the forearc, with major variations in the stress ratio but without significant changes in the orientation of the maximum stress axes.

- Brittle deformation of the ophiolite started shortly after it was incorporated into the forearc, i.e., after ca. 5.7 Ma.

- The stress field induced by the subduction of the Chile Ridge system resulted in different styles of brittle deformation within and around the ophiolite. In the plutonic units early generated compressional structures were progressively counterclockwise rotated (about $60^{\circ}$ ) as a result of rotation of whole ophiolite package (represented by stress field ' $B$ '). New compressional structures were then generated because of the continuous subduction (represented by stress field 'A'). The development of these new structures was synchronous with rotation of the ophiolite.

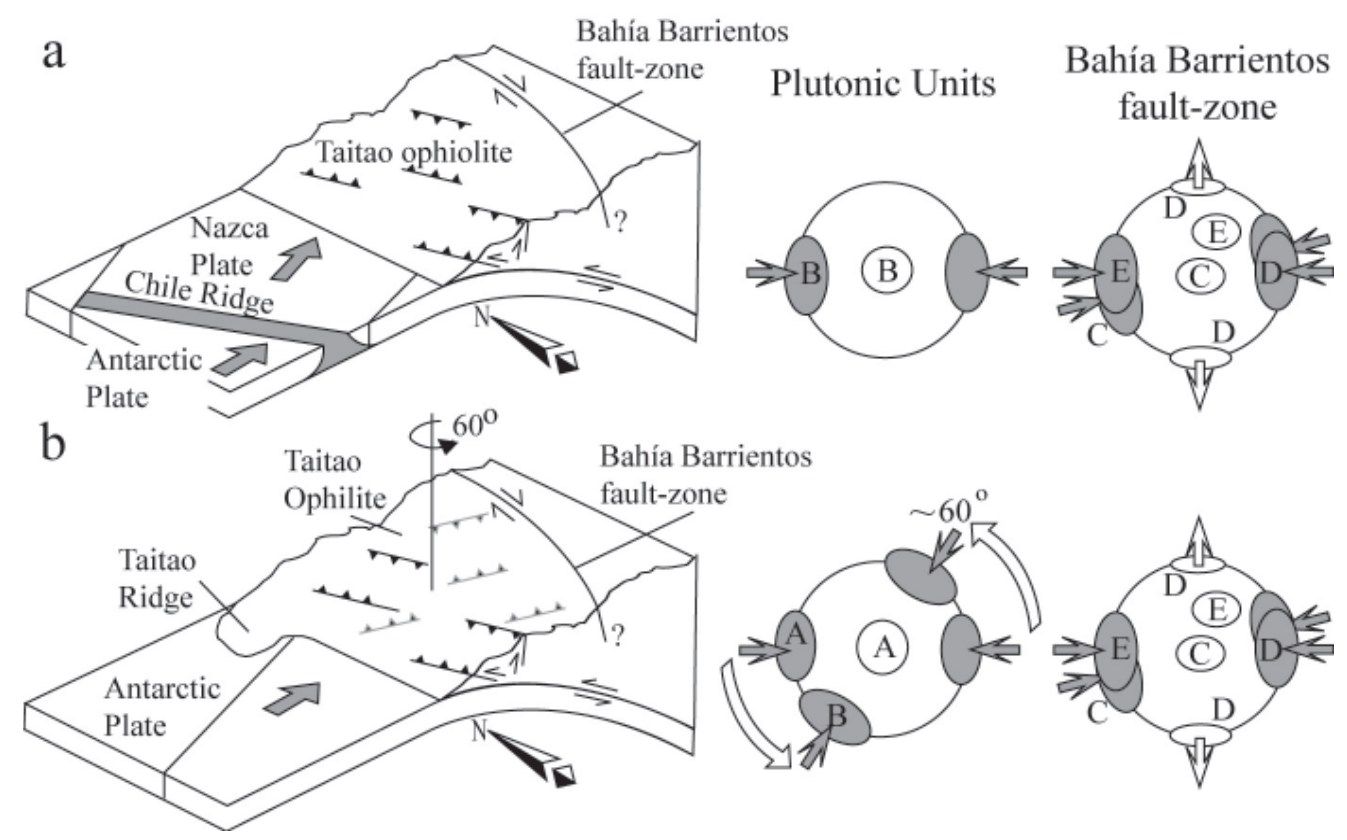

FIG. 6. Proposed tectonic model showing the generation of brittle structures developed in the plutonic units of the ophiolite and in its eastern margin. a. Developing of dip-slip structures due to fast subduction of the Nazca plate in the plutonic units of the ophiolite and of strike-slip structures in its eastern border (Bahía Barrientos fault-zone), all generated before rotation of the ophiolite; $\mathbf{b}$. Developing of new dip-slip structures in the plutonic units of the ophiolite after rotation (most probably driven by the activity of the Bahía Barrientos fault-zone). Abbreviations are indicated in figure 1 and orientations of stress axes are in figure 3. White arrows (ellipses) indicate the orientation of $\sigma_{3}$ axes while grey arrows (ellipses) indicate the orientation $\sigma_{1}$ axes. 
- The subduction of two different oceanic plates resulted in different style of brittle deformation in the eastern border of the ophiolite (southern and central parts of the Bahía Barrientos fault-zone). During periods of relatively strong compression (subduction of the Nazca plate) the fault-zone experienced dip- and strike-slip movements (represented by stress fields ' $\mathrm{C}$ ' and ' $\mathrm{D}$ '). In contrast, during periods of relatively weak compression (subduction of the Antarctic plate) the fault-zone experienced a mixture of thrust and strike-slip movements (mostly represented by stress field 'E').

\section{Acknowledgements}

This work was supported by the grant -in-aid of the Science Research Project No 13373004 financed by the Ministry of Education, Sports, Science and Technology (MEXT) of Japan. Special thanks to the crew of the R/V Petrel for their professional work and cooperation. Field data collection was assisted by Drs. Y. Kaneko (Yokohama National University), M. Terabayashi (Kagawa University), T. Otha and T. Komiya (Tokyo Institute of Technology), S. Kagashima (Yamagata University), I. Katayama, (Hiroshima University), Miss C. Herrera (Universidad de Chile), Mrs. M. Schilling (Universidad de Chile), S. Yamamoto, T. Shibuya, Y. Kon (Tokyo Institute of Technology) and R. Endo (University of Tsukuba). We would like to thank Dr. J. Cembrano, Dr. G. Yáñez and an anonymous reviewer for their helpful comments which help to improve the manuscript.

\section{References}

Angelier, J. 1994. Fault slip analysis and paleostress reconstruction. In Continental Deformation (Hancock, P.; editor). Pergamon press: 53-100.

Anma, R.; Armstrong, R.; Danhara, T.; Orihashi, Y.; Iwano, H. 2006. Zircon sensitive high mass-resolution ion microprobe $\mathrm{U}-\mathrm{Pb}$ and fission-track ages for gabbros and sheeted dykes of the Taitao Ophiolite, Southern Chile, and their tectonic implications. The Island Arc 15: $130-142$.

Ballard, D. 1981. Generalizing the Hough transform to detect arbitrary shapes. Pattern Recognition 13: 111-122.

Bourgois, J.; Lagabrielle, Y.; Le Moigne, J.; Urbina, O.; Janin, M-Ch.; Beuzart, P. 1993. Preliminary results of a field study of the Taitao Ophiolite (southern Chile): Implications for the evolution of the Chile Triple Junction. Ofioliti 18 (2): 113-129.

Bourgois, J.; Martin, H.; Lagabrielle, Y.; Le Moigne, J.; Frutos Jara, J. 1996. Subduction erosion related to spreading-ridge subduction: Taitao Peninsula. Geology 24 (8): 723-726.

Cande, S.; Leslie, B. 1986. Late Cenozoic tectonics of southern Chile trench. Journal of Geophysical Research 91 (B1): 471-496.

Cembrano, J.; Schermer, E.; Lavenu, A.; Sanhueza, A. 2000. Contrasting nature of deformation along an intra-arc shear zone, the Liquiñe-Ofqui fault-zone, Southern Chilean Andes. Tectonophysics 319: 129-149.

Cembrano, J.; Lavenu, A.; Reynolds, P.; Arancibia, G.; López G.; Sanhueza, A. 2002. Late Cenozoic transpressional ductile deformation north of the Nazca-South America-Antarctica triple junction. Tectonophysics 354: 289-314.

DeMets, C.; Gordon, R.; Argus, D.; Stein, S. 1994. Effect of recent revisions to the geomagnetic reversal time scale on estimates of current plate motions. Geophysical Research Letters 21: 2191-2194.

Dilek, Y.; Thy, P.; Moores, E.; Ramsden, T. 1990. Tectonic evolution of the Troodos Ophiolite within the Thetyan framework. Tectonics 9 (4): 811-823.

Doblas, M. 1998. Slickenside kinematic indicators. Tectonophysics 295: 187-197.

Fisher, R. 1953. Dispersion on a sphere. Proceedings of the Royal Society of London A217: 295-305.

Fitch, D. 1972. Plate convergence, transcurrent faults, and internal deformation adjacent to Southeast Asia and Western Pacific. Journal of Geophysical Research 77 (23): 4432-4460.

Forsythe, R.; Nelson, E. 1985. Geological manifestations of the ridge collision: Evidence from the Golfo de Penas-Taitao Basin, southern Chile. Tectonophysics 4 (5): 447-495.

Guivel, C.; Lagabrielle, Y.; Bourgois, J.; Maury, R.; Martin, H.; Arnaud, N.; Cotten, J. 1996. Magmatic responses to active spreading ridge subduction: Multiple magma sources in the Taitao Peninsula region ( $46^{\circ}-47^{\circ}$, Chile Triple Junction). In Symposium International sur la Géodynamique Andine, No. 3: 575-578. Saint-Malo.

Guivel, C.; Lagabrielle, Y.; Bourgois, J.; Maury, R.; Fourcade, S.; Martin, H.; Arnaud, N. 1999. New geochemical constraints for the origin of ridge-subduction-related plutonic and volcanic suites from the Chile triple junction (Taitao Peninsula and Site 862, LEG ODP141 on the Taitao ridge). Tectonophysics 311: 83-111.

Hervé, F.; Fanning, M.; Thomson, S.; Pankhurst, R.;Anma, R.; Veloso, A.; Herrera, C. 2003. SHRIMP U-Pb and FT Pliocene ages of the near-trench granites in the Taitao Peninsula, southern Chile. In Simposium South American on Isotope Geology, No. 4, 1: 190-193. Salvador de Bahía (Brasil).

Keading, M.; Forsythe, R.; Nelson, E. 1990. Geochemistry of the Taitao Ophiolite and near-trench intrusions from the Chile margin triple junction. Journal of South American Earth Sciences 3 (4): 161-177.

Kent, J. 1992. The Fisher-Binghman distribution on a sphere. Journal of the Royal Statistical Society B44: 71-80.

Lagabrielle, Y.; Le Moigne, J.; Maury, R.; Cotten, J.; 
Bourgois, J. 1994. Volcanic record of the subduction of an active spreading ridge, Taitao Peninsula (southern Chile). Geology 22: 515-518.

Lagabrielle, Y.; Guivel, C.; Maury, R.; Bourgois, J.; Fourcade, S.; Martin, H. 2000. Magmatic-tectonic effects of high thermal regime at the site of active ridge subduction: The Chile triple junction model. Tectonophysics 326: 255-268.

Lagabrielle, Y.; Suárez, M.; Rossello, E.; Herail, G.; Martinod, J.; Regnier, M.; de la Cruz, R. 2004. Neogene to Quaternary tectonic evolution of the Patagonian Andes at the latitude of the Chile Triple Junction. Tectonophysics 385: 211-241.

Moores, E.; Vine, F. 1971. The Troodos massif, Cyprus, and other ophiolites as oceanic crust: Evaluation and implications. Philosophical Transactions of the Royal Society of London A268: 443-466.

Mpodozis, C.; Hervé, M.; Nasi, C.; Soffia, J.; Forsythe, R.; Nelson, E. 1985. El magmatismo plioceno de la península Tres Montes y su relación con la evolución del punto triple de Chile. Revista Geológica de Chile 25-26: 13-28.

Nelson, E.; Forsythe, R.; Diemer, J.; Allen, M.; Urbina, O. 1993. Taitao Ophiolite: A ridge collision ophiolite in the forearc of southern Chile $\left(46^{\circ} \mathrm{S}\right)$. Revista Geológica de Chile 20: 137-166.

Nelson, E.; Forsythe, R.; Arit, I. 1994. Ridge collision tectonics in terrane development. Journal of South American Earth Sciences 7 (3/4): 271-278.

Otsubo, M.; Yamaji, A. 2006. Improved resolution of the multiple inverse method by eliminating erroneous solutions. Computers and Geosciences 32: 1221-1227.

Petit, J. 1987. Criteria for the sense of movement on fault surfaces in brittle rocks. Journal of Structural Geology 9: 597-608.

Ramsay, J.; Lisle, R. 2000. The techniques of modern structural geology. Applications of continuum mechanics in structural geology 3. Academic Press: 608 p. New York.
Somoza, R. 1998. Updated Nazca (Farallon)-South America relative motions during the last $40 \mathrm{My}$ : implications for mountain building in the central Andean Region. Journal of South American Earth Sciences 11 (3): 211-215.

Tauxe, L. 1998. Paleomagnetic principles and practice. Modern approaches in geophysics. Kluwer Academic: 300 p. Amsterdam.

Thomson, S. 2002. Late Cenozoic geomorphic and tectonic evolution of the Patagonian Andes between latitudes $42^{\circ} \mathrm{S}$ and $46^{\circ} \mathrm{S}$ : an appraisal based on fission-track results from the transpressional intra-arc Liquiñe-Ofqui fault-zone. Geological Society of America Bulletin 114 (9): 1159-1173.

Varga, R.; Moores, E. 1985. Spreading structure of the Troodos Ophiolite, Cyprus. Geology 13: 846-850.

Veloso, E.;Anma, R.; Yamazaki, T. 2005. Tectonic rotations during the Chile Ridge collision and obduction of the Taitao Ophiolite (southern Chile). The Island Arc 14: 599-615.

Yamaji, A. 2000. The multiple inverse method: A new technique to separate stresses from heterogeneous fault-slip data. Journal of Structural Geology 22: 441-452.

Yáñez, G.; Cembrano, J. 2000. Tectonic models for ridge collision at a continental plate boundary: The case of Juan Fernández ridge and Chile rise, Preliminary Results. In Congreso Geológico Chileno, No. 9, expanded abstracts: 649-654. Puerto Varas.

Yáñez, G.; Cembrano, J.; Pardo, M.; Ranero, C.; Selles, D. 2002. The Challenger-Juan Fernández-Maipo major tectonic transition of the Nazca-Andean subduction system at $33-34^{\circ} \mathrm{S}$ : geodynamic evidence and implications. Journal of South American Sciences 15: 23-38.

Yáñez, G.; Cembrano, J. 2004. Role of viscous plate coupling in the late Tertiary Andean tectonics. Journal of Geophysical Research 109, B02407. doi: 10.1029/2003JB002494. 